\title{
Prognostic value of acetylcholine challenge test: a prospective study
}

\author{
Q T PHAM, ${ }^{1} \mathrm{~J}$ M MUR, ${ }^{2} \mathrm{~N}$ CHAU,${ }^{3} \mathrm{M}$ GABIANO,${ }^{4} \mathrm{~J}$ C HENQUEL,${ }^{1}$ AND D TECULESCU 1
}

From Inserm U 14 Physiopathologie Respiratoire, ${ }^{1}$ Case Officielle No 1054511 Vandoeuvre-les-Nancy Cédex, INRS Section d'Epidémiologie, ${ }^{2}$ avenue de Bourgogne, 54500 Vandoeuvre-les-Nancy Cédex, Inserm U 115 Applications Médicales de l'Informatique, ${ }^{3}$ avenue de la Forêt de Haye, 54505 Vandoeuvre-les-Nancy Cédex, and Lormines, ${ }^{4} 57703$ Hayange, France

ABSTRACT Eleven hundred and nine iron mine workers aged 35 to 55 with normal chest radiographs were submitted to a pulmonary examination consisting of a questionnaire, a clinical examination, and pulmonary function testing including an acetylcholine challenge test. A positive response (decrease of $\mathrm{FEV}_{1}$ of more than 10\%) was observed in 210 subjects (Ace ${ }^{+}$). The remaining 899 had a negative response $\left(\mathrm{Ace}^{-}\right)$. Bronchitis, asthma, dyspnoea, and obstructive syndrome were more frequent in the $\mathrm{Ace}^{+}$group. Five years later, 820 subjects were reexamined: occasional cough and sputum and chronic bronchitis appeared more frequently among subjects without symptoms at the first examination but with a positive acetylcholine challenge test. The obstructive syndrome was more often observed and regressed more rarely in the Ace ${ }^{+}$ group. The results confirm the use of a test of bronchial hyperreactivity as a means of identifying subjects at risk from chronic obstructive lung disease.

The concept that bronchial hyperreactivity was important in the evolution of chronic obstructive lung disease (COLD) was introduced by Dutch

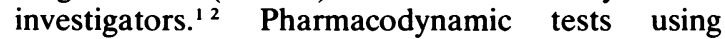
acetylcholine, metacholine, or histamine may be used to evaluate the degree of hyperreactivity. ${ }^{3-6}$ Initial work by Tiffeneau $e \mathrm{al}^{3-6}$ on the ventilatory effect of acetylcholine concerned asthmatic subjects during remission. It is now known, however, that bronchial hyperreactivity may occur not only in asthma but also in other conditions as a response to inhaled irritants and infections. The mechanism of this hyperreactivity is complex and not yet fully understood; nevertheless, it remains a criterion to be taken into account when evaluating the diagnosis and prognosis of COLD, the decrease in forced expiratory volume in one second $\left(\mathrm{FEV}_{1}\right)$ being correlated with the degree of methacholine reactivity as was pointed out by Barter and Campbell ${ }^{7}$ and Minette $^{8}$ in their longitudinal studies of bronchitic patients.

In 1973 a recommendation was made by the working group on "functional respiratory tests in

Received 15 November 1982

Accepted 14 March 1983 epidemiology" of the European Society for Clinical Respiratory Physiology at a meeting held in Laanaken to include a pharmacodynamic test (the acetylcholine challenge test) in the set of respiratory function tests to be used in epidemiology.

Therefore, in order to explore the predictive value of an acetylcholine challenge test we have performed it in an epidemiological survey of iron miners and related the results to the evolution of clinical and functional pulmonary symptoms five years later. ${ }^{9}$

\section{Material and methods}

In 1975 (first examination) 1109 workers employed in iron mines, aged 35 to 55 , with a normal chest radiograph, were submitted to a bronchial challenge test with acetylcholine that was performed at the end of all examinations planned for the epidemiological survey. Each subject inhaled a one in a thousand acetylcholine aerosol delivered by a Gauchard AMP 7 nebuliser for three minutes. The amount of acetylcholine delivered during this time was $1200 \mu \mathrm{g}$. More than $90 \%$ of the particles issued from the nebuliser are below $5 \mu$ in size. (After explanation, all the subjects agreed to the test. Precautions had been taken to avoid any incident and 
none occurred; some mild bronchospasm was rapidly alleviated with a salbutamol inhaler.)

Immediately after the aerosol inhalation, each subject was asked to perform three forced expiratory volumes to measure $F E V_{1}$, and the best value was compared with that obtained before the inhalation of acetylcholine. Decreases exceeding $10 \%$ were considered as a positive response, indicating a bronchial hyperreactivity. ${ }^{*}$

Other examination undertaken during the survey were as follows:

(a) Questionnaire on chronic bronchitis and emphysema of the European Community of Steel and Coal (ECSC) derived from that of the Medical Research Council, with additional questions concerning work hazards.

(b) Clinical examination (including chest and heart auscultation and measurement of systemic arterial pressure).

(c) Spirometric measurements: three vital capacity (VC) and three $\mathrm{FEV}_{1}$ were performed using a 91 watersealed spirometer (Boulitte $\mathrm{N}$ ). The largest values of $\mathrm{VC}$ and of $\mathrm{FEV}$, were taken.

(d) Functional residual capacity (FRC), residual volume (RV), $\mathrm{TCO} / \mathrm{ml} / \mathrm{min}$ Torr, and fractional uptake of $\mathrm{CO}$ (FuCO) by the steady state method were obtained using the Pneumotest Alveotest Jaeger apparatus.

The same procedures were repeated five years later (second examination) in 820 subjects by the same investigators with the same apparatus.

Table 1 Characteristics of groups at first examination

\begin{tabular}{|c|c|c|}
\hline & $\begin{array}{l}\text { Negative } \\
\text { Ace } \\
(n=899)\end{array}$ & $\begin{array}{l}\text { Positive } \\
\text { Ace }{ }^{+} \\
(n=210)\end{array}$ \\
\hline $\begin{array}{ll}\text { Age (years) } & \begin{array}{l}\bar{x} \\
\text { SD }\end{array}\end{array}$ & $\begin{array}{r}45 \cdot 6 \\
4 \cdot 8\end{array}$ & $\begin{array}{r}46 \cdot 4 \\
4 \cdot 6\end{array}$ \\
\hline $\begin{array}{l}\text { Smoking habits ( } \% \text { of each group): } \\
\text { Non-smokers } \\
\text { Ex-smokers } \\
\text { Smokers }<20 \text { cig/day } \\
\text { Smokers }>20 \text { cig/day }\end{array}$ & $\begin{array}{l}16 \cdot 8 \% \\
10 \cdot 1 \\
39 \cdot 9 \\
29 \cdot 6\end{array}$ & $\begin{array}{l}10 \cdot 5 \% \\
12.9 \\
40 \cdot 0 \\
32 \cdot 9\end{array}$ \\
\hline $\begin{array}{l}\text { Duration of work in mines (years): } \\
<20 \\
20-29 \\
>30\end{array}$ & $\begin{array}{l}12 \cdot 7 \\
73 \cdot 0 \\
14 \cdot 3\end{array}$ & $\begin{array}{l}10 \cdot 5 \\
78 \cdot 1 \\
11 \cdot 4\end{array}$ \\
\hline
\end{tabular}

No significant difference is observed between the two groups.

*The limit of $10 \%$ was chosen on the basis of the histogram of FEV , variation after acetylcholine that showed a bimodal distribution and a clear cut off at this limit. It corresponded also to an approximate doubling of the coefficient of variation of FEV, observed in normal subjects by the same technicians with the same apparatus. ${ }^{10}$

\section{Results}

In 1975,899 subjects were found to have a negative response to acetylcholine challenge and $210(19 \%)$ a positive one. For the sake of clarity, subjects with a negative test will be given the symbol $\mathrm{Ace}^{-}$and those with a positive result $\mathrm{Ace}^{+}$.

Age, smoking habits, and duration of work did not differ significantly between the two groups (table 1). The percentage of above ground workers (having never worked underground) is higher in Ace $^{-}(15.4 \%)$ than in Ace $^{+}(6.7 \%)$ group (table 2$)$.

Bronchitis, asthma, dyspnoea, and the obstructive syndrome (VC $>80 \%$ of theoretical values and $\mathrm{FEV}_{\mathrm{A}} / \mathrm{VC}<65 \%$ ) were more frequent in group $\mathrm{Ace}^{+}$, whereas no significant difference was seen for the restrictive syndrome $\left(\mathrm{VC}<80 \%\right.$ and $\mathrm{FEV}_{1}<$ $80 \%$ of theoretical values) (tables 3 and 4 ).

Five years later, the percentage of subjects dead, lost, or re-examined was similar for $\mathrm{Ace}^{-}$and $\mathrm{Ace}^{+}$ groups (3.34\% v $2.86 \%$ deceased, $11.57 \% \vee 9.05 \%$ lost, $11.46 \% \vee 12.46 \%$ answered to a questionnaire but not re-examined, $73.64 \% \vee 75.24 \%$ reexamined).

Table 2 Work history of groups at first examination

\begin{tabular}{lll}
\hline & $\begin{array}{l}A c e^{-} \\
(n=899)\end{array}$ & $\begin{array}{l}A_{c e^{+}} \\
(n=210)\end{array}$ \\
\hline Percentage of time of work underground: & 15.4 & 6.7 \\
0 & $5 \cdot 1$ & 5.2 \\
$<25$ & 8.9 & 8.6 \\
$25-50$ & 13.9 & $15 \cdot 2$ \\
$50-75$ & 56.7 & 64.3 \\
$>75$ & & \\
$\chi^{2}$ test $\mathrm{p}<0.05$ & & \\
\hline
\end{tabular}

Table 3 Percentage occurrence of clinical symptoms in each group at first examination

\begin{tabular}{|c|c|c|}
\hline & $\begin{array}{l}A c e^{-} \\
(n=899)\end{array}$ & $\begin{array}{l}A c e^{+} \\
(n=210)\end{array}$ \\
\hline $\begin{array}{l}\text { Cough and sputum: } \\
\text { No symptoms } \\
\text { Occasional cough and/or sputum } \\
\text { Chronic bronchitis* } \\
\chi^{2} \text { test } \mathrm{p}<0.001\end{array}$ & $\begin{array}{l}57 \cdot 0 \\
24 \cdot 6 \\
23 \cdot 4\end{array}$ & $\begin{array}{l}38 \cdot 1 \\
25 \cdot 2 \\
36 \cdot 7\end{array}$ \\
\hline $\begin{array}{l}\text { Asthma: } \\
\text { No symptoms } \\
\text { Wheeze } \\
\text { Asthma } \dagger \\
\chi^{2} \text { test } \mathrm{p}<0.0001\end{array}$ & $\begin{array}{r}89.3 \\
7.2 \\
3.5\end{array}$ & $\begin{array}{l}75.7 \\
12.9 \\
10 \cdot 5\end{array}$ \\
\hline $\begin{array}{l}\text { Dyspnoea: } \\
\text { No dyspnoea } \\
\text { D grade } 1 \\
D \text { grade } \geqslant 2 \\
\chi^{2} \text { test } p<0.001\end{array}$ & $\begin{array}{r}72.6 \\
13.5 \\
7.9\end{array}$ & $\begin{array}{l}53.3 \\
22.9 \\
12.9\end{array}$ \\
\hline
\end{tabular}

Chronic bronchitis, ${ }^{*}$ asthma, $\dagger$ are defined according to definitions of American Thoracic Society 1962. 
Table 4 Functional abnormalities observed at first examination. Percentage in each group

\begin{tabular}{lll}
\hline & $\begin{array}{l}A c e^{-} \\
(n=899)\end{array}$ & $\begin{array}{l}A_{\left(n={ }^{+}\right.} \\
(n=210)\end{array}$ \\
\hline Spirometry: & 97.6 & 85.2 \\
Normal & 1.3 & 2.4 \\
Restrictive syndrome* & 1.1 & 12.4 \\
Obstructive syndrome & & \\
$\chi^{2}$ test p < 0.001 & & \\
\hline
\end{tabular}

* Restrictive syndrome $=\mathrm{VC}<80 \%$ of theoretical values.

tObstructive syndrome $=\mathrm{FEV}_{1} / \mathrm{VC}$ ratio $<$ to $80 \%$ of theoretical values.

Among the 820 subjects re-examined 662 were $\mathrm{Ace}^{-}$and $158 \mathrm{Ace}^{+}$. The percentage of retired subjects is higher in the $\mathrm{Ace}^{+}$group especially for those who worked above ground $(51.9 \% v 33.6 \%)$. In the second examination occasional cough and sputum and chronic bronchitis were more frequent among the subjects in the $\mathrm{Ace}^{+}$group (table 5). Among subjects who were wheezing in 1975, asthma appears more often in the $\mathrm{Ace}^{+}$than in the $\mathrm{Ace}^{-}$subjects (table 6). Dyspnoea is more frequent in the $\mathrm{Ace}^{+}$group than in the Ace ${ }^{-}$(table 7) and the obstructive syndrome appears more frequently and regresses more rarely in the $\mathrm{Ace}^{+}$group (table 8). No difference was observed in the evolution of the restrictive syndrome or in abnormalities of the RV or $\mathrm{CO}$ tests between the groups.

The reduction of tobacco consumption was similar in the two groups. Although there is a higher proportion of retired subjects in the $\mathrm{Ace}^{+}$group who would not be subjected to occupational

Table 5 Evolution of symptoms: cough and sputum

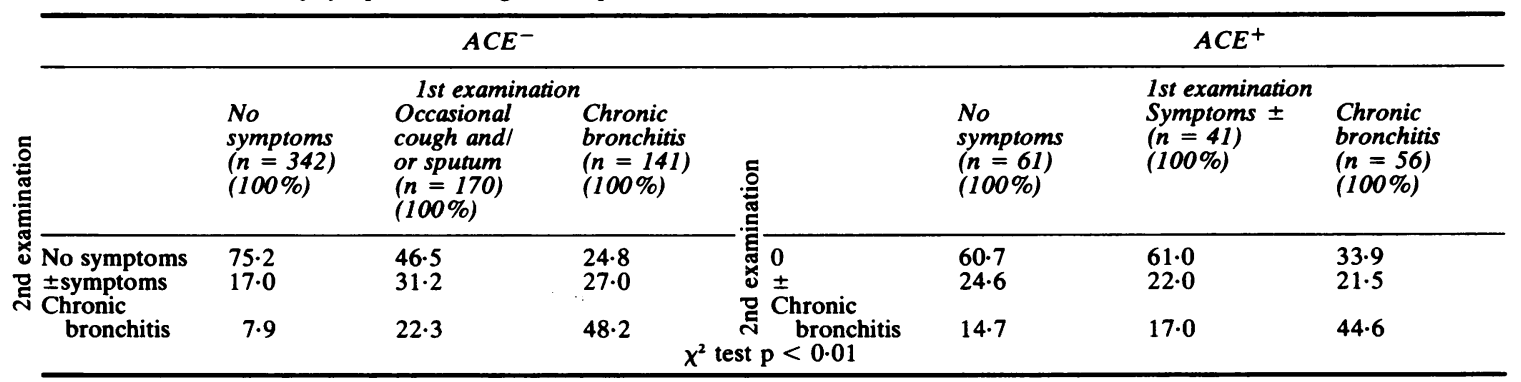

Table 6 Evolution of symptoms: asthma

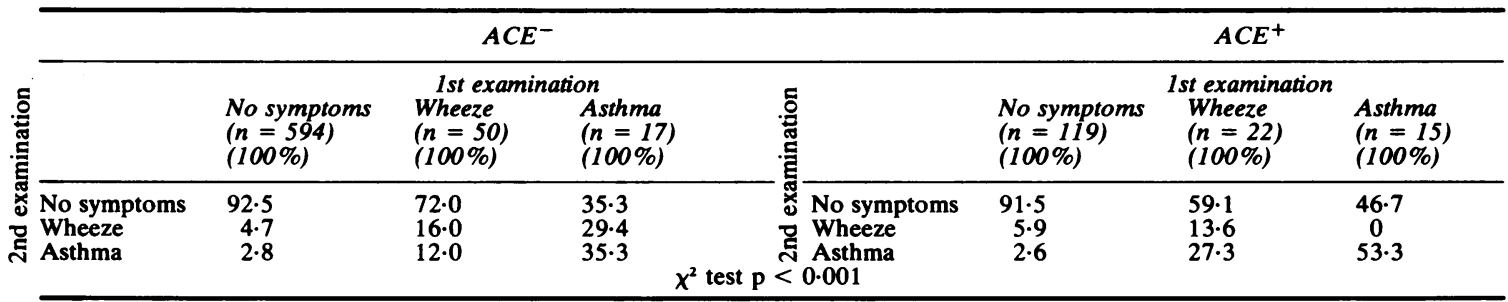

Table 7 Evolution of symptoms: dyspnoea

\begin{tabular}{|c|c|c|c|c|c|c|c|}
\hline \multicolumn{5}{|c|}{$A C E^{-}$} & \multicolumn{3}{|c|}{$A C E^{+}$} \\
\hline & $\begin{array}{l}\text { No } \\
\text { dyspnoea } \\
(n=478) \\
(100 \%)\end{array}$ & $\begin{array}{l}\text { 1st examination } \\
\text { Dyspnoea } \\
\text { grade } 1 \\
(n=84) \\
(100 \%)\end{array}$ & $\begin{array}{l}\text { Dyspnoea } \\
\text { grade } \geqslant 2 \\
(n=51) \\
(100 \%)\end{array}$ & . ํㅗㅀ & $\begin{array}{l}\text { No } \\
\text { dyspnoea } \\
(n=85) \\
(100 \%)\end{array}$ & $\begin{array}{c}\text { 1st examination } \\
\text { Dyspnoea } \\
\text { grade } 1 \\
(n=37) \\
(100 \%)\end{array}$ & $\begin{array}{l}\text { Dyspnoea } \\
\text { grade } \geqslant 2 \\
(n=20) \\
(100 \%)\end{array}$ \\
\hline $\begin{array}{l}\text { No dyspnoea } \\
\text { Dyspnoea }\end{array}$ & $79 \cdot 2$ & $59 \cdot 5$ & $39 \cdot 2$ & $\begin{array}{l}\text { ్ㅠ No dyspnoea } \\
\text { ㅇ Dyspnoea }\end{array}$ & 76.4 & $37 \cdot 8$ & $25 \cdot 0$ \\
\hline $\begin{array}{l}\text { Grade } 1 \\
\text { Grade }>2\end{array}$ & $\begin{array}{r}13.4 \\
7.4\end{array}$ & $\begin{array}{r}31.0 \\
9.5\end{array}$ & $\begin{array}{l}37 \cdot 3 \\
23 \cdot 5\end{array}$ & $\begin{array}{l}\text { Grade 1 } \\
\mathrm{p}<\mathbf{0 . 0 1}\end{array}$ & $\begin{array}{r}14 \cdot 1 \\
9 \cdot 5\end{array}$ & $\begin{array}{l}48 \cdot 6 \\
13.6\end{array}$ & $\begin{array}{l}45 \cdot 0 \\
30 \cdot 0\end{array}$ \\
\hline
\end{tabular}


Table 8 Evolution of lung function

\begin{tabular}{|c|c|c|c|c|c|}
\hline \multirow{3}{*}{$\begin{array}{l}\text { No obstructive } \\
\text { syndrome } \\
\text { Obstructive } \\
\text { syndrome }\end{array}$} & \multicolumn{2}{|r|}{$A C E^{-}$} & & \multicolumn{2}{|c|}{$A C E^{+}$} \\
\hline & $\begin{array}{l}\text { No obstructive } \\
\text { syndrome } \\
(n=635) \\
(100 \%)\end{array}$ & $\begin{array}{l}\text { examination } \\
\text { Obstructive } \\
\text { syndrome } \\
(n=7)\end{array}$ & .્ટ & $\begin{array}{l}\text { No obstructive } \\
\text { syndrome } \\
(n=135) \\
(100 \%)\end{array}$ & $\begin{array}{l}\text { mination } \\
\text { Obstructive } \\
\text { syndrome } \\
(n=15) \\
(100 \%)\end{array}$ \\
\hline & $\begin{array}{r}97 \cdot 6 \\
2 \cdot 4\end{array}$ & $\begin{array}{l}42 \cdot 8 \\
58 \cdot 2\end{array}$ & $\begin{array}{l}\text { No obstructive } \\
\text { No syndrome } \\
\text { o Obstructive } \\
\text { syndrome } \\
<0.001\end{array}$ & $\begin{array}{r}90.3 \\
9.7\end{array}$ & $\begin{array}{l}20 \cdot 0 \\
80 \cdot 0\end{array}$ \\
\hline
\end{tabular}

hazards, the decrease of FEV was significantly greater in the $\mathrm{Ace}^{+}$group (fig).

\section{Discussion}

The results of the challenge test observed at first examination appear to be related to other symptomatic (bronchial) and functional (obstructive syndrome) manifestations. Similar observations were made by Minette $e t a^{11}$ and Guerrin $e^{2} a^{12}$ in coal miners and by Navratil et $a l^{13}$ and by Bouhuys et al ${ }^{14}$ in cotton mill workers. The choice of $10 \%$ (or more) fall of $\mathrm{FEV}_{1}$ as the limit for a positive response to the challenge test may be discussed. Though Tiffeneau and Drutel in the first work on challenge test proposed this limit, ${ }^{6}$ others actually preferred a limit of $20 \% .{ }^{1415}$ If this limit had been applied to our study only 54 subjects would have fulfilled this criterion of positive response to the challenge test. Thus in order to increase the number in the $\mathrm{Ace}^{+}$group the limit of $10 \%$ fall in FEV after the challenge test was chosen. This limit corresponds with the one recommended by Eiser et al. ${ }^{17}$

More than half the subjects $(54 \%)$ who had a "positive" response at the first examination became "negative" at the second examination five years later (table 9). Despite this, the test seems to have a prognostic value. Cough and sputum as symptoms of

Table 9 Evolution of bronchial reactivity

\begin{tabular}{lc}
\hline 1st examination & 2nd examination \\
\hline Ace $^{-} \mathrm{n}=662(100 \%) —$ Ace $^{-} 85.4 \%$ \\
& Ace $^{+} 14.6 \%$ \\
Ace $^{+} \mathrm{n}=158(100 \%) \longrightarrow$ Ace $^{-} 54.0 \%$ \\
\end{tabular}

chronic bronchitis developed more frequently in the subjects with a positive response to the challenge test and the stability of symptoms and of the obs-

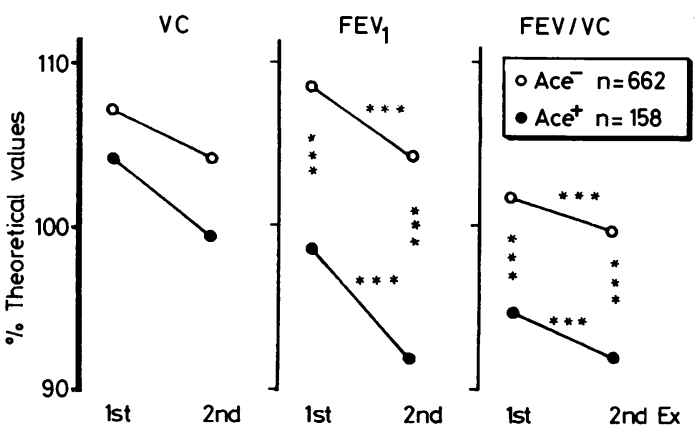

Mean values of $F E V$, and $F E V, / V C$ are lower at first and second examinations in Ace ${ }^{+}$group. Decrease of means values is significantly higher for FEV $/ V C$ in the Ace ${ }^{+}$ group. ${ }^{*} p<0.05 ;{ }^{* *} p<0.01 ;^{* * *} p<0.001$.

tructive syndrome is greater in the $\mathrm{Ace}^{+}$group. The $\mathrm{FEV}_{1}$ and $\mathrm{FEV}_{1} / \mathrm{VC}$ decreased more between the two periods in the $\mathrm{Ace}^{+}$group (but it is statistically significant only for $\mathrm{FEV}_{1} / \mathrm{VC}$ ). This finding is similar to, but not so obvious, as that of Minette et al ${ }^{11}$ in bronchitic coal miners and of Barter and Campbell ${ }^{7}$ in patients with chronic bronchitis. Britt et al, during a four year survey of siblings of patient with COLD, reported that the loss of lung function was five times greater in those who had hyperreactive airways than in those without hyperreactivity. ${ }^{18}$ All these results justify the use of a challenge test in epidemiological surveys to show bronchial hyperreactivity, even if only a single dose of acetylcholine is used, as in this study. It may contribute to the identification of subjects at risk from COLD.

This work was supported by a grant of the European Economic Community (EEC) No 7246-24008. We thank Mrs R Deniau and A Liegeois for technical help and Miss P Ulmer, B Clement, and Miss MC Rohrer for the typing and the figures. We also thank M Betz, J P Toamain, V Baudin, C Garrigue, and M Weiss for technical help. 


\section{References}

' Orie NJM, Sluiter HJ, De Vries K, Tammeling GJ, Witkop J. The host factor in bronchitis. In: Orie NJM, Sluiter HJ, eds. Bronchitis, an international symposium 27-29 April 1960. Assen, Netherland: Royal Van Corcum, 1961;43-59.

${ }^{2}$ De Vries K, Booij-Noord H, Grobler NJ, Sluiter HJ, Tammeling GJ, Orie NGM. Allergie et hyperreactivité dans la bronchite chronique. In: Symposium bronchite emphysème (Stresa, 21-22 Avril 1966). Collection d'Hygiène et de Médecine du Travail 1967;5:67-77.

${ }^{3}$ Tiffeneau R. L'hyperexcitabilité acétylcholinique du poumon, critère physiopharmacodynamique de la maladie asthmatique. Presse Med 1955;63:227-30.

4 Tiffeneau R. Examen pulmonaire de l'asthmatique. Déductions diagnostiques, prognostiques et thérapeutiques. Masson ed, 1957.

s Tiffeneau R, Beauvallet M. Production exclusive deffets pulmonaires locaux par inhalation d' aérosols d acetylcholine. Son utilisation comme test d insuffisance respiratoire. Semaine des hôpitaux de Paris 1945;21:154-5.

- Tiffeneau R, Drutel P. Les aérosols d'acétylcholine dans Pexploration fonctionnelle des poumons. Etude de leur action motrice et sensitive. Applications pratiques. Poumon 1955;11:388-468.

' Barter CE, Campbell AH. Relationship of constitution factors and cigarette smoking to decrease in 1 second forced expiratory volume. Am Rev Respir Dis 1976;113:305-14.

- Minette A. Valeur pronostique de la sensibilité respiratoire à Pacétylcholine dans un groupe de mineurs de charbon. Rev Inst Hyg Mines 1973;28:147-52.

9 Pham QT, Mur JM, Beigbeder R, Deniau R, Leonet O. Incidence à long terme de basses teneurs de nuisances gazeuses sur l'appareil respiratoire. Résultats d' une enquête épidémiologi- que chez les ouvriers des mines de fer du Bassin de Lorraine. Rev Epidemiol Santé Publique 1977;25:255-73.

${ }^{10}$ Pham QT, Michailesco JP, Pirrolet H, Sadoul P. Interprétation des variations du volume expiratoire maximum seconde après aérosol d'acétylcholine et d'allergène chez $\mathrm{P}$ asthmatique jeune. Journal Français de Médecine et Chirurgie Thoraciques 1968;22:533-42.

"Minette A, Marcq M, Gepts L. Prognostic value of a positive acetylcholine test regarding VC and FEV, in coal miners with a history of chronic bronchitis. Bull Europ Physiopath Respir 1978; 14: 167-75.

${ }_{12}$ Guerrin F, Voisin C, Robin H, Prevost B. Aperçu de P' experience lilloise du test à Pacétylcholine chez le mineur de charbon. $R e v$ Inst Hyg Mines 1973;28:129-32.

${ }^{13}$ Navratil M, Roth Z. The prevalence of the acetylcholine reactivity in cotton mill workers. Rev Inst Hyg Mines 1973;28: 141-6.

14 Bouhuys $A$. The forced expiratory volume in healthy man and in textile workers. Am Rev Respir Dis 1963;87:63-8.

is Harjula R. The use of both the metacholine provocation test and isoprenaline in the diagnosis of byssinosis. Rev Inst Hyg Mines 1974;29:34-6.

${ }^{16}$ Hargreave FE. Non-specific bronchial reactivity. In: De Kock MA, Nadel JA, Lewis CM, eds. Mechanisms of airways obstruction in human respiratory disease. Proceedings of the international symposium Tygerburg South Africa, 1978. Rotterdam: AA Balkema, 1979:77-87.

${ }^{17}$ Eiser NM, McCrae KD, Guz A. Evaluation and expression of bronchial provocation tests. Clin Respir Physiol 1981;17:427-40.

18 Britt J, Cohen B, Menkes H, et al. Airways reactivity and functional deterioration in relatives of COLD patients. 22nd Aspen Lung Conference. Chest 1980; suppl 260-1. 